\title{
Dampak covid-19 terhadap Usaha Mikro, Kecil dan Menengah
}

\author{
Siti Nuzul Laila Nalini \\ IAIN PONOROGO \\ nuzullailanalini@gmail.com
}

\begin{abstract}
Abstrak Pandemi COVID-19 memberikan dampak terhadap ekonomi, sosial, dan politik bukan hanya negara-negara besar akan tetapi hampir seluruh negara di dunia. Indonesia yang didominasi oleh Usaha Mikro, kecil, dan Menengah (UMKM) perlu memberikan perhatian khusus terhadap sektor ini karena kontribusi UMKM terhadap perekonomian nasional yang cukup besar Dalam penulisan menggunakan penelitian kepustakaan yaitu dalam proses pengambilan datanya tidak perlu terjun kedalam lapangan secara langsung tetapi mengambil berbagai sumber referensi yang mendukung suatu penelitian ini. Penelitian ini berjenis penelitian kualitatif. Hasil penelitian Jurnal ini yaitu untuk mengetahui tantangan ekonomi dan bisnis akibat pandemi COVID-19 dan pendekatan yang dilakukan, yaitu pendekatan secara makro, dan pendekatan secara mikro. Adapun tujuan dari penelitian ini yaitu untuk menganalisa dampak pandemi COVID-19 terhadap eksistensi UMKM di Indonesia dan bagaimana solusi dalam membantu UMKM bertahan dalam situasi pandemi COVID-19. Akibat Covid-19 tersebut memberikan dampak yang cukup besar pada perekonomian di Indonesia terutama pada UMKM.

Kata Kunci UMKM, tenaga kerja, bantuan keuangan, kebijakan struktural.
\end{abstract}

\section{PENDAHULUAN}

Pandemi virus Corona bukan hanya sekedar bencana kesehatan, virus yang dikenal sebagai Covid-19 ini telah menimbulkan kekacauan di sektor ekonomi. Tidak hanya industri besar, pandemi virus Corona telah membuat pelaku UKM di Indonesia mulai gelisah. Sebuah studi menyebut jika Covid-19 membuat Indonesia mengalami penurunan persentase pertumbuhan ekonomi sebesar $0.1 \%$ di tahun 2020. Secara garis besar, berikut merupakan dampak nyata yang disebabkan Covid-19 terhadap sektor UKM di Indonesia.Pandemi COVID-19 yang terjadi pada saat ini memberikan dampak terhadap berbagai sektor. Pada tataran ekonomi global, pandemi COVID-19 memberikan dampak yang signifikan terhadap perekonomian domestik negara-bangsa dan keberadaan UMKM. Laporan Organisation for Economic Co-operation and Development (OECD) menyebutkan pandemi ini berimplikasi pada ancaman krisis ekonomi yang cukup besar yang ditandai dengan berhentinya aktivitas produksi di berbagai negara, jatuhnya tingkat konsumsi masyarakat, hilangnya kepercayaan konsumen, jatuhnya bursa saham yang pada akhirnya mengarah pada ketidakpastian. 1. OECD memprediksi bahwa akan terjadi penurunan tingkat output antara seperlima hingga seperempat di berbagai negara, dengan pengeluaran konsumen berpotensi turun sekitar sepertiga. 2. Prediksi ini juga mengancam perekonomian nasional Indonesia. Aknolt Kristian Pakpahan menyebutkan ada tiga implikasi bagi Indonesia terkait pandemi COVID-19 ini yakni sektor pariwisata, perdagangan, dan investasi.3 Indonesia yang didominasi oleh keberadaan Usaha Mikro, Kecil, dan Menengah (UMKM) sebagai tulang punggung perekonomian nasional juga 
terdampak secara serius tidak saja pada aspek total produksi dan nilai perdagangan akan tetapi juga terhadap jumlah tenaga kerja yang harus kehilangan pekerjaannya karena pandemi ini. Data dari Kementerian Koperasi dan Usaha Kecil Menengah (KemenkopUKM) menunjukkan bahwa pada tahun 2018 terdapat 64.194.057 UMKM yang ada di Indonesia (atau sekitar 99 persen dari total unit usaha) dan mempekerjakan 116.978.631 tenaga kerja (atau sekitar 97 persen dari total tenaga kerja di sektor ekonomi). Tujuan penelitian ini adalah yaitu untuk menganalisa dampak pandemi COVID-19 terhadap eksistensi UMKM di Indonesia dan bagaimana solusi dalam membantu UMKM bertahan dalam situasi pandemi COVID-19.

\section{LANDASAN TEORI}

\section{A. 1. Usaha Mikro Kecil dan Menengah (UMKM)}

a. Pengertian UMKM

Usaha Mikro Kecil dan Menengah UMKM merupakan usaha yang memiliki peran yang cukup tinggi terutama di Indonesia. Dengan banyaknya jumlah UMKM maka akan semakin banyak penciptaan kesempatan kerja bagi para pengangguran. Selain itu UMKM juga dapat dijadikan sebagai sumber pendapatan khususnya didaerah pedesaan dan rumah tangga yang berpendapatan rendah. Peran UMKM tidak dapat di ragukan lagi dalam mendukung peningkatan pendapatan masyarakat. Pengertian UMKM terdapat beberapa macam diantaranya. Definisi yang berkaitan dengan UMKM menurut: a. Definisi UMKM diatur dalam Undang-Undang Republik Indonesia No.20 Tahun 2008 tentang UMKM. Pasal 1 dari UU, dinyatakan bahwa Usaha mikro adalah usaha produktif milik orang perorangan atau badan usaha perorangan yang memiliki kriteria usaha mikro sebagaimana diatur dalam UU tersebut. Usaha kecil adalah usaha ekonomi yang produktif yang usahanya berdiri sendiri, yang dilakukan oleh orang perorangan atau badan usaha yang bukan merupakan anak perusahan, dikuasai atau menjadi bagian, baik langsung maupun tidak langsung, dari usaha menengah atau usaha besar yang memenuhi kriteria usaha kecil sebagaimana yang dimaksud dalam UU tersebut. Sedangkan usaha mikro adalah usaha ekonomi produktif yang pelaksanaannya berdiri sendiri yang dilakukan oleh perorangan atau badan usaha yang bukan merupakan anak perusahaan atau bukan anak cabang perusahaan yang dimiliki, dikuasai, atau menjadi bagian baik langsung maupun tidak langsung, dari usaha mikro, usah kecil atau usaha besar yang memenuhi kriteria usaha mikro sebagaimana dimaksud dalam UU tersebut. Di dalam Undangundang tersebut, kriteria yang digunakan untuk mendefinisikan UMKM seperti yang tercantum dalam Pasal 6 adalah nilai kekayaan bersih atau nilai aset tidak termasuk tanah dan bangunan tempat usaha, atau hasil penjualan tahunan. b. Ketentuan undang undang No. 9 Tahun 1995 tentang usaha kecil dan kemudian dilaksanakan lebih lanjut dengan peraturan pemerintah nomor 44 tahun 1997 tentang kemitraan, dimana pengertian UMKM adalah sebagaimana di atur Undang- undang No. 20 tahun 2008 UMKM adalah usaha ekonomi produktif yang berdiri sendiri, yang dilakukan oleh perorangan atau badan usaha yang bukan merupakan anak perusahan atau bukan cabang yang dimiliki, dikuasai atau menjadi bagian baik langsung maupun tidak langsung dari usaha menengah atau usaha besar yang memenuhi kriteria usaha kecil 100011 c. Menurut badan Pusat Statistik tahun 2003 mendefinisikan UMKM menurut 2 kategori yaitu: Menurut omset. Usaha kecil adalah usaha yang mempunyai aset tetap kurang dari Rp. 200.000 .000 dan omset pertahun kurang Rp.1.000.000.000 ii. Menurut jumlah tenaga kerja. Usaha kecil adalah usaha yang mempunyai tenaga kerja sebanyak 5 sampai 9 orang tenaga kerja. Industri rumah tangga adalah industri yang memperkerjakan kurang dari 5 orang. UMKM adalah 
usaha yang mempunyai modal awal yang kecil atau nilai kekayaan (aset) yang kecil dan jumlah pekerja yang kecil (terbatas), nilai modal (aset) atau jumlah pekerjaannya sesuai definisi yang diberikan oleh pemerintah atau intitusi lain dengan tujuan tertentu (Sukirno, 2004: 365) d. Menurut Departemen Perindustrian dan Perdagangan, UMKM adalah kelompok industri kecil modern, industri tradisional, dan industri kerajinan yang mempunyai investasi modal untuk mesinmesin dan peralatan sebesar Rp.70.000.000,00 ke bawah dan usahanya dimiliki oleh warga Negara Indonesia. e. Menurut Suprapti (2005:48) UMKM adalah badan usaha baik perorangan atau badan hukum yang memiliki kekayaan bersih (tidak termasuk tanah dan bangunan) sebanyak Rp. 200.000.000,00 dan mempunyai hasil penjualan pertahun sebanyak Rp. 1.000.000.000,00 dan berdiri sendiri.

\section{COVID}

World Health Organization (WHO) menjelaskan bahwa Coronaviruses (Cov) adalah virus yang menginfeksi sistem pernapasan. Infeksi virus ini disebut COVID19. Virus Corona menyebabkan penyakit flu biasa sampai penyakit yang lebih parah seperti Sindrom Pernafasan Timur Tengah (MERS-CoV) dan Sindrom Pernafasan Akut Parah (SARS-CoV). Virus ini menular dengan cepat dan telah menyebar ke beberapa negara, termasuk Indonesia. Seseorang dapat tertular COVID-19 melalui berbagai cara, yaitu: 1 . Tidak sengaja menghirup percikan ludah dari bersin atau batuk penderita COVID-19 2. Memegang mulut atau hidung tanpa mencuci tangan terlebih dulu setelah menyentuh benda yang terkena cipratan air liur penderita COVID-19 3. Kontak jarak dekat dengan penderita COVID-19, misalnya bersentuhan atau berjabat.

Di Indonesia, penyebaran virus ini dimulai sejak tanggal 02 Maret 2020, diduga 150 berawal dari salah satu warga negara Indonesia yang melakukan kontak langsung dengan warga negara asing. Seiring dengan berjalannya waktu, penyebaran covid-19 telah mengalami peningkatan yang signifikan. Hal tersebut dapat diketahui dari data berikut. Saat ini yang sudah terinfeksi Covid-19 di Indonesia sebanyak 7.775 orang dan yang dinyatakan Sembuh sebanyak 960 orang dan yang meninggal sebanyak 647 orang hal ini mengajarkan kita agar berhati-hati dalam menjaga kebersihan dan juga menaati peraturan pemerintah agar pandemi ini cepat berakhir dari negara kita Indonesia. Dan ketika kita melihat penyebaran covid-19 terbesar berada di pulau jawa terutama di daerah Surabaya dan Jakarta disini bisa kita lihat bahwa kuranya kesadaran masyarakat dalam menyikapi pandemic atau covid-19 yang terjadi sehingga masih banyak orang yang masih tidak menggunakan masker, masih berkumpul di keramain, dan tidak melakukan social distancing sehingga seharusnya pemerintah lebih tegas lagi dalam menangani masyarakat yang belum mempunyai kesadaran, dan perlunya kesadaran bersama tersebut untuk memutus penyebaran covid-19 agar dapat segera berakhir dan kehidupan kita dapat berjalan seperti biasa lagi.

\section{METODOLOGI PENELITIAN}

Penelitian ini bertujuan untuk untuk menganalisa dampak pandemi COVID-19 terhadap eksistensi UMKM di Indonesia dan bagaimana solusi dalam membantu UMKM bertahan dalam situasi pandemi COVID-19. Dalam penulisan ini peneliti menggunakan penelitian kepustakaan yaitu dalam proses pengambilan datanya tidak perlu terjun kedalam lapangan secara langsung tetapi mengambil berbagai sumber refernsi yang mendukung suatu penelitian ini. Penelitian ini berjenis penelitian kualitatif. Teknik pengumpulan data yaitu menyimak serta mencatat informasi penting dalam melakukan analisis data dengan cara reduksi data, display data dan gambaran kesimpuan sehingga 
mendapatkan suatu gambaran kesimpulan mengenai studi literatur untuk dikembangkan dalam penelitian ini dan untuk validasi datanya menggunakan triangulasi sumber data.

\section{HASIL PENELITIAN}

Dalam menghadapi tantangan ekonomi dan bisnis akibat pandemi COVID-19 ini diperlukan berbagai jenis pendekatan, diantaranya adalah pendekatan secara makro melalui kebijakan pemerintah maupun dengan pendekatan secara mikro melalui manajemen UMKM secara bisnis. Pada pendekatan makro yaitu melalui kebijakan pemerintah, Laporan OECD3 menyebutkan bahwa untuk membantu UMKM saat ini, pemerintah harus mempertimbangkan kurang lebihnya tiga tindakan penting, yaitu Pertama, pemerintah harus mengumumkan langkah-langkah dukungan ekonomi dan bisnis saat ini dan secara progresif yang lebih terfokus untuk pemulihan. Pengaturan waktu dan kecepatan sangatlah penting. Menarik langkah-langkah dukungan ekonomi dan bisnis terlalu cepat dapat menyebabkan kegagalan besar-besaran pada perusahaan dan membuat persaingan semakin lemah, tetapi disisi lain dukungan ekonomi dan bisnis yang berkepanjangan dapat mengakibatkan distorsi, mengurangi insentif untuk beradaptasi dan berinovasi, dan memerangkap sumber daya dalam kegiatan yang tidak produktif. Kedua, pemerintah harus memastikan bahwa arus perusahaan yang keluar dan masuk dilakukan secara bertahap dilanjutkan dengan cara yang mendukung pemulihan inklusif (yaitu, tanpa lebih lanjut membebani mereka yang paling terkena dampak krisis, seperti pemuda, wanita dan migran). Ada peluang untuk meningkatkan status kepailitan, memfasilitasi penutupan bisnis tidak produktif dan restrukturisasi bisnis yang layak, dan meningkatkan kemampuan pengusaha untuk memulai bisnis baru setelah kegagalan. Karena kebangkrutan dapat meningkat secara dramatis, reformasi kebijakan harus dapat membatasi efek negatif dan mengurangi biaya pribadi bagi pengusaha gagal yang jujur. Semua ini membutuhkan pengembangan kriteria untuk menilai UMKM mana yang harus mendapatkan dukungan selama pemulihan dan transisi ke model bisnis baru. Menerapkan kriteria tradisional untuk mengidentifikasi bisnis yang "layak" - seperti data neraca atau riwayat kredit baru-baru ini - mungkin tidak bekerja dengan efektif. Sebagai contoh, memanfaatkan perkembangan Fintech dan alat-alat digital untuk penilaian risiko kredit yang lebih efektif, pemberian layanan dan pemantauan menyeluruh dapat membantu mengatasi keterbatasan pendekatan tradisional untuk pembiayaan bisnis pada saat ketidakpastian seperti saat ini belum pernah terjadi sebelumnya. Sejauh ini, pemerintah belum memanfaatkan instrumen ini secara efektif. Selain itu, instrumen pembiayaan nonutang harus digunakan lebih banyak untuk mengatasi lebih beragam kebutuhan dalam populasi UMKM dan memperkuat struktur modal mereka (mis. Ekuitas, pembiayaan mezzanine, leasing atau anjak piutang). Ketiga, dukungan pemerintah harus menjangkau para pengusaha dan UMKM yang dapat meningkatkan ketahanan ekonomi dan masyarakat di era pasca-COVID. Awal yang inovatif, kewirausahaan dan model bisnis baru harus dipromosikan. Pada saat yang sama, UMKM tradisional yang sebagian besar menghilang dan perusahaan mikro yang berjuang untuk mengambil manfaat dari transisi digital harus mempercepat digitalisasi dan adopsi teknologi, perubahan organisasi dan peningkatan keterampilan. Keluar dari krisis, UMKM harus muncul dengan perlengkapan yang lebih baik secara digital dan dengan kemampuan tenaga kerja yang diperkuat. Hanya sedikit inisiatif kebijakan yang bertujuan untuk meningkatkan ketahanan jangka panjang dari bisnis yang sudah mapan dan potensi pertumbuhan UMKM. Misalnya, Korea dan Irlandia telah bertindak untuk membantu bisnis kecil mengadopsi proses kerja baru, mempercepat digitalisasi dan menemukan pasar baru. Langkah-langkah dukungan 
struktural seperti itu, bersama-sama dengan persyaratan cerdas, harus dimasukkan dalam fase selanjutnya dari respons kebijakan. Adapun dalam upaya menangani pandemi COVID-19, Tim Ahli Policy Brief Bidang Ekonomi di bawah naungan Direktorat Inovasi dan Science Techno Park Universitas Indonesia (DISTP UI) merumuskan sebuah Policy Brief 7, Rekomendasi yang diberikan adalah agar pemerintah dapat membagi fokus penanganan pandemi COVID-19 dari sisi ekonomi menjadi dua periode utama, yaitu periode jangka pendek dan mendesak (emergency response: disaster relief process, lives first) dan periode jangka menengah (minimize recession). Pada periode jangka pendek dan mendesak, pemerintah berfokus pada pengurangan penambahan korban jiwa COVID19 dengan penekanan pada stimulus sektor kesehatan dan bantuan kesejahteraan bagi rakyat yang terdampak. Ada dua pihak yang perlu mendapat perhatian pemerintah, yakni: pekerja atau rumah tangga dan perusahaan atau industri. Pemerintah juga direkomendasikan untuk memberikan perhatian khusus kepada industri yang memiliki kesulitan untuk membayar kredit/cicilan (credit constraint) khususnya UMKM dan industri yang terkena dampak paling besar dari tidak berjalannya perekonomian dalam beberapa waktu terakhir (kerajinan tangan, tekstil, restoran, hotel, industri hiburan, $e$ commerce, gig-economy). Pada sektor perbankan juga akan menghadapi masalah likuiditas (liquidity constraints) dan kredit macet (non performing loan). Bank Sentral bisa membeli surat utang pemerintah (government bonds) yang dapat menurunkan suku bunga. Di samping itu, likuiditas dari lembaga keuangan nonperbankan, terutama asuransi dan dana pensiun perlu juga mendapatkan perhatian. Pemerintah diharapkan dapat mengantisipasi misalnya tekanan likuiditas dari sisi dana pensiun sebagai akibat dari penarikan JHT para pekerja yang mengalami PHK. Sejumlah usulan kebijakan jangka menengah diantaranya, memastikan dunia usaha untuk langsung beroperasi, menjaga kesinambungan sektor logistik dan mendorong kemandirian industri alat kesehatan menjadi kunci. Selanjutnya, menjaga kesinambungan sektor pangan, makanan dan minuman. Kemudian, pemerintah mampu memastikan terciptanya penguatan industri dalam negeri terutama industri alat kesehatan sebagai antisipasi merebaknya pandemi di masa yang akan datang. Jika kebijakan dari sisi penawaran telah diambil maka fokus kebijakan jangka menengah selanjutnya yang dapat diambil oleh pemerintah adalah upaya-upaya pemulihan agregate demand. Penghapusan pajak seperti PPN dan PPh setelah pandemi akan membantu mendorong permintaan (demand). Selain itu, pemerintah harus memberi stimulus kepada rumah tangga untuk mengonsumsi barang manufaktur, dan sektor jasa seperti restoran, hotel dan pariwisata serta angkutan dan penerbangan. Secara mikro melalui kebijakan perusahaan, dalam rangka menata kembali kondisi ekonomi UMKM yang melemah atau resesi akibat covid-19 ini diperlukan pengelolaan siklus bisnis secara Manajemen Businees Cycle mengingat kondisi lingkungan bisnis sangatlah dinamis sehingga harus selalu dievaluasi dan diperbaiki siklus usahanya sehingga usaha bisa bertahan dan dapat terus berkembang dengan cara, yaitu (1) Menciptakan perubahan sebagai peluang untuk mencapai sukses, (2) Melihat perbedaan antar orang atau fenomena sebagai peluang bukan kesulitan, (3) Bereksperimen untuk mencari pembaharuan menuju pertumbuhan bisnis, (4) Menjadi pakar untuk usaha sendiri, (5) Menjadi pelayan untuk orang lain dan memiliki sifat rendah hati. Dengan kemampuan pengelolaan siklus bisnis tersebut, sebuah perusahaan pun harus dapat bertumbuh dan berkembang dalam jangka panjang dengan memperhatikan factorfaktor diantaranya 1. Strategic Intent (Kesatuan Visi dan Misi) 2. Decision Maker (Pengambilan Keputusan yang Cepat dan Tepat), 3. Funding (Manajemen Keuangan Terencana), 4.Business Plan (Perencanaan Bisnis), 5.Manajemen Tim, 6.Execution, 
7.Timing (Saat yang Tepat memulai usaha). Mengelola siklus bisnis melalui proses perencanaan, pengorganisasian, penggunaan sumberdaya-sumberdaya organisasi dan dengan perencanaan dan pengorganisasian harus memperhatikan siklus bisnis pada 4 periode yaitu 1.Puncak Siklus (Kemakmuran) 2. Resesi (Kemerosotan), 3. Palung (Depresi Paling Parah) 4.Pemulihan (Ekspansi) yang dapat menggambarkan klasifikasi jenis bisnis dengan bidang usaha atau peluang usaha pasca covid - 19,8 sehingga pelaku bisnis UMKM dapat mengindentifikasi jenis bisnis sesuai siklus bisnis yang dialami pada masa pandemi COVID-19 dan mengambil tindakan yang sesuai dengan jenis bisnisnya. Tabel 1. Data business cycle berdasarkan jenis bisnis pada lima bidang usaha sebagai basis peluang usaha.

Beberapa pengusaha menilai bagaimana kebutuhan yang muncul terkait dengan krisis bisnis COVID-19 dapat memengaruhi bisnis mereka dan mengambil tindakan yang tepat, dengan mempertimbangkan juga beberapa aspek kompetitif seperti perencanaan skenario, analisis pemangku kepentingan, pengembangan strategi, komunikasi eksternal dan internal. Beberapa indikator dapat digunakan di perusahaan untuk mengevaluasi kapasitas reaktifnya dan memahami kemungkinan dampak perubahan digital untuk mengurangi efek negatif dari masalah krisis COVID-19. Setelah latar belakang teoretis jelas, dan begitu analisis status eksternal dan internal telah dilakukan, UKM harus merefleksikan model bisnis mereka sendiri. Transformasi digital tidak hanya berarti memperkenalkan teknologi baru untuk melakukan aktivitas yang ada: itu adalah proses mendesain ulang seluruh model bisnis. Demi mendukung usaha pengusaha dalam mengimplementasik model bisnis baru dan transformasi digital pada usaha mereka, penting bagi pemerintah untuk membuat kebijakan struktural untuk kepentingan jangka panjang. Kebijakan ini tidak saja digunakan untuk menghadapi pandemi COVID-19 tapi juga era Industri 4.0 kedepannya. Kebijakan ini meliputi kebijakan-kebijakan jangka pendek bagi UMKM yakni pengenalan teknologi digital dan pelatihan bagi para pelaku dan pekerja UMKM serta kebijakan panjang bagi UMKM untuk beradaptasi dengan penggunaan teknologi untuk proses produksi, penggunaan Keterangan Perdagangan Industri Jasa Ekstraktif Real Estate Peluang Usaha Kemakmuran 84200133 Peluang usaha yang bisa dikembangkan dan dipertahankan manajemennya Resesi Ekonomi 322 108 Peluang usaha perlu ditingkatkan manajemennya Palung (Depresi Parah) 52601 14 Peluang usaha perlu pemulihan dan peningkatan manajemen Pemulihan (Ekspansi) 3 210006 Peluang usaha perlu dilakukan pemulihan / ekspansi dan ditingkatkan manajemen dengan maksimal Jenis Bisnis Indikator Business Cycle 152 Abdurrahman Firdaus Thaha media teknologi digital untuk mempromosikan produk UMKM, dan menemukan pasar potensial bagi produk yang dihasilkan. Dalam jangka pendek, perlu adanya pendampingan bagi para pelaku UMKM untuk dapat memanfaatkan media $e$ commerce (belanja daring) untuk menjual produk-produk mereka. Data dari Badan Pusat Statistik menunjukkan bahwa pada tahun 2018 baru 3,79 juta UMKM (atau sekitar 8 persen) yang memanfaatkan platform online untuk memasarkan produknya.11 Tentu situasi seperti ini dapat menjadi salah satu jalan keluar untuk meningkatkan jumlah UMKM yang memanfaatkan platform online tadi. Kemudian, kebijakan jangka pendek tadi dilanjutkan dengan kebijakan jangka panjang. Pemerintah dapat memulainya dengan membuat peta jalan pengembangan UMKM dalam menghadapi era Industri 4.0 mulai dari pelatihan ulang (retraining) para pekerja UMKM guna beradaptasi dengan penggunaan teknologi produksi baru dan teknologi digital, pembangunan infrastruktur telekomunikasi dan program internet masuk desa, pelibatan dunia akademisi dan usaha besar dalam pendampingan pengenalan dan penggunaan teknologi produksi dan media 
digital, serta menghidupkan kembali program kemitraan usaha besar dan UMKM. Kebijakan struktural ini dilakukan untuk mendukung penguatan UMKM sekaligus mendukung pengembangan UMKM di era Industri 4.0. Kebijakan yang mendukung harus mempertimbangkan perbedaan antar sektor agar lebih relevan dengan kebutuhan spesifik mereka; mereka juga harus lebih transparan jika mereka ingin memberikan subsidi secara langsung kepada pengusaha swasta, mereka bertujuan untuk membantu mengatasi krisis.9 Sementara itu, transformasi digital mengikuti munculnya keterampilan digital baru dan adopsi alat digital. Ini adalah proses transformasi yang membutuhkan penataan ulang model bisnis sebelumnya untuk memberi ruang bagi praktik baru, lebih efektif dan efisien.

\section{KESIMPULAN}

Dampak wabah Covid-19 kepada perekonomian dialami oleh seluruh negara di dunia, termasuk di Indonesia mengalami dampak perekonomian yang cukup besar. UMKM dalam hal ini menjadi bagian yang sangat terpukul dalam krisis ini, memperhatikan kontribusi UMKM terhadap jumlah unit usaha, sumbangan PDB, serapan tenaga kerja, ekspor dan investasi terhadap perekonomian yang ada di Indonesia yang sangat besar. Kebijakan pemerintah tersebut juga dibagi dalam berbagai strategi jangka pendek, menengah dan jangka panjang, antara lain pada jangka pendek dan mendesak, pemerintah berfokus pada pengurangan penambahan korban jiwa COVID-19 dengan penekanan pada stimulus sektor kesehatan dan bantuan kesejahteraan bagi rakyat yang terdampak, dan untuk kebijakan jangka menengah diantaranya, memastikan dunia usaha untuk beroperasi, menjaga kesinambungan sektor logistik dan mendorong kemandirian industri alat kesehatan, sedangkan strategi jangka panjang difokuskan pada pengenalan dan penggunaan teknologi digital bagi UMKM sekaligus persiapan untuk memasuki era Industri. Pada masa pandemi COVID-19 yang tidak ada kepastian kapan akan berakhirnya pandemi tersebut, maka UMKM selaku entitas bisnis harus dapat mengelola manajemen business cycle dengan memperhatikan kategori jenis bisnisnya pada 4 siklus bisnis, 1.Puncak Siklus (Kemakmuran) 2. Resesi (Kemerosotan ), 3. Palung (Depresi Paling Parah) 4.Pemulihan (Ekspansi). Dengan mengelola manajemen business cycle dengan baik dan perubahan bisnis model dan transformasi digital dengan menyesuaikan kondisi pandemi COVID-19 ini maka diharapkan strategi perusahaan UMKM dapat berhasil mengatasi tantangan. Akhir kata, sinergi antara kebijakan makro pemerintah dengan kebijakan mikro perusahaan diharapkan dapat membantu UMKM dalam mengatasi tantangan menghadapi krisis pandemi COVID19.

\section{DAFTAR PUSTAKA}

Abrar, T. F. (2020, April 19). Retrieved from Jangan Kaget, Ini Prediksi Sri Mulyani Soal Ekonomi RI: https://www.cnbcindonesia.com/market/20200419092613-17152924/jangan-kaget-ini-prediksi-sri-mulyani-soal-ekonomi-ri

Asmini, I. N. (n.d.). Manajemen Bussines Cycle Sebagai Basis Peluang Usaha Pasca Covid-19. Suatu strategi pemulihan Ekonomi Masyarakat.

Atra, P. A. (n.d.). Retrieved from Dampak Covid-19 Terhadap Sektor UKM di Indonesia: https://maucash.id/dampak-covid19-terhadap-bisnis-usaha-kecil-menengahukm-di-indonesia 
Budiyanto, A. (n.d.). 8 Juta UMKM.

CASALINO, N. D. (n.d.). A Qualitty Management Training system Concering ISO Standards . Productivity and Quality Management .

Casalino, N. Z. (n.d.). Digital Strategies And Organizational Perfomances Of SMEs In The Age of Coronavirus: Balance Digital Transformations with An Effective Bussines Reselience. Law and Economics Yearly Review Jurnal-LEYR.

Fadila, R. U. (2020, Mei 09). Retrieved from 1.785 Koperasi dan 163.713 UMKM Terdampak Pandemi Covid-19: https://www.pikiran-rakyat.com/ekonomi/pr01379615/1785-koperasi-dan-163713-umkm-terdampak-pandemi-covid-19

Pakpahan, A. K. (n.d.). Retrieved from COVID-19 dan Implikasi Bagi Usaha Mikro, Kecil, dan Menengah.

Sakti, N. W. (2020, Oktober 05). Retrieved from Perekonomian Indonesia Pasca-Pandemi Covid-19: https://money.kompas.com/read/2020/05/10/091500226/perekonomianindonesia-pasca-pandemi-covid-19?page=all

Sri Mulyani Indrawati, S. N. (2020, April 17). Pemerintah Waspada Dampak Pandemi Covid-19 Terhadap Ekonomi Indonesia. Retrieved from https://www.kemenkeu.go.id/publikasi/siaran-pers/siaran-pers-pemerintahwaspada-dampak-pandemi-covid-19-terhadap-ekonomi-indonesia/

Sri Mulyani, S. N. (2020). Pemerintah Waspada Dampak Pandemi Covid-19 Terhadap Ekonomi Indonesia. 